\title{
BIOETHANOL POTENTIAL FROM WHOLE PARTS OF CASSAVA PLANT IN INDONESIA
}

\section{POTENSI BIOETANOL DARI SELURUH BAGIAN TANAMAN SINGKONG DI INDONESIA}

\author{
Felen Suryani Dinata dan Irvan S. Kartawiria*)
}

\begin{abstract}
Chemical Engineering Department, Faculty of Life Sciences and Technology, Swiss German University The Prominence Tower, Jalan Jalur Sutera Barat No. 15, Alam Sutera, Tangerang 15143, Indonesia E-mail: irvan.kartawiria@sgu.ac.id
\end{abstract}

Makalah: Diterima 18 November 2020; Diperbaiki 03 Maret 2021; Disetujui 20 April 2020

\section{ABSTRAK}

Singkong adalah bahan baku bioetanol yang menjanjikan karena semua bagian dari tanaman singkong termasuk umbi, batang, daun, serta limbah pengolahan seperti kulit dan ampas dapat digunakan dalam produksi bioetanol. Akan tetapi, potensi total bioetanol dari seluruh bagian tanaman singkong belum dipelajari. Penelitian ini mengkaji dan menghitung rata-rata hasil bioetanol dari setiap bagian tanaman singkong, serta menghitung potensi bioetanol dari seluruh bagian tanaman singkong khususnya di Indonesia. Umbi singkong segar, batang segar, daun segar, kulit segar, dan ampas kering memiliki rata-rata hasil bioetanol masing-masing 180 L/ton, 155 L/ton, 75 L/ton, 160 L/ton, dan 390 L/ton. Jika seluruh tanaman singkong digunakan untuk memproduksi bioetanol, tanaman singkong yang menghasilkan satu ton umbi singkong segar dapat menghasilkan $400 \mathrm{~L}$ bioetanol. Dengan skenario total area perkebunan yang dipanen seluas 700.000 ha dan produktivitas singkong 22,5 ton/ha/tahun, potensi bioetanol dari seluruh bagian tanaman singkong di Indonesia adalah 6,3 miliar L/tahun. Akan tetapi, penggunaan seluruh bagian tanaman singkong untuk memproduksi bioetanol tidak memungkinkan secara teknis dan ekonomis, mengingat adanya pemanfaatan lain dari singkong. Potensi bioetanol dari seluruh bagian tanaman singkong dengan mempertimbangkan pemanfaatan lain adalah 2,9 miliar L/tahun. Bahkan ketika umbi singkong digunakan untuk pemanfaatan lain, bioetanol dari batang, daun, kulit, dan ampas singkong yang tidak termanfaatkan masih signifikan dan patut dipertimbangkan.

Kata kunci: bioetanol, tanaman singkong, limbah

\section{ABSTRACT}

Cassava is a promising bioethanol feedstock as all parts of cassava plant including its tuber, stem, leaves, along with processing waste such as peel and dregs can be used in bioethanol production. However, bioethanol potential from the whole parts of cassava plant has not been studied. This research reviewed and calculated the average bioethanol yield from each part of the cassava plant, and calculated bioethanol potential from the whole parts of cassava plant, especially in Indonesia. Fresh cassava tuber, fresh stem, fresh leaves, fresh peel, and dry dregs are found to have average bioethanol yield of $180 \mathrm{~L} /$ ton, $155 \mathrm{~L} /$ ton, $75 \mathrm{~L} /$ ton, $160 \mathrm{~L} /$ ton, and $390 \mathrm{~L} /$ ton, respectively. If the whole cassava plant were utilized for bioethanol production, cassava plants that produce a ton of fresh cassava tuber can yield $400 \mathrm{~L}$ bioethanol. With a scenario of total area harvested 700,000 ha and cassava productivity of $22.5 \mathrm{ton} / \mathrm{ha} /$ year, bioethanol potential from whole cassava plant in Indonesia is 6.3 billion L/year. However, using all the cassava plant for bioethanol production is impractical and uneconomical, considering other utilization of cassava. The bioethanol potential from whole parts of cassava plant after considering other use of plant becomes 2.9 billion L/year. Even when the cassava tuber is used for other utilization, bioethanol from unused cassava stem, leaves, peel, and dregs is still significant and worth considering.

Keywords: bioethanol, cassava plant, waste

\section{INTRODUCTION}

Regulation of the Minister of Energy and Mineral Resources of The Republic of Indonesia No. $12 / 2015$ stated that by January 2020, E10 should be implemented in transportation non-public services, industry, and commercial sector. However, the regulation is currently not yet implemented because of several factors such as high bioethanol production cost compared to convetional gasoline, and insufficient feedstock supply that affects the production line. Currently, bioethanol in Indonesia is produced from molasses feedstock that has limited resources due to competition with other industries, and increasing price of molasses contributes to the final bioetannol production cost (Suryana et al., 2012).

Industrialization of bioethanol requires raw material with abundant availability (Haditjaroko et al., 2014). In Indonesia, cassava is potentially abundant and its availability assure the sustainability of bioethanol production. Furthermore, cassava is considered as one of the promising bioethanol feedstock. Nuwamanya et al. (2012) summarize 
several advantages of cassava as bioethanol feedstock such as it has high productivity and yield, requires minimum labor work, low management cost, and can grow on marginal land or degraded soils. Baeyens et al. (2015) calculated that bioethanol from cassava feedstock is more economical than bioethanol from corn or sugarcane. Rao (as cited in Wang, 2007) compared bioethanol potential from several crops, shown in Table 1, and the result showed that among other crops, cassava tuber has the highest bioethanol yield per hectare area per year. Additionally, the other parts of the plant, such as stem, leaves, along with processing waste such as peel and pile can also be used as bioethanol feedstock.

Indonesia has a high potential to utilize cassava as bioethanol feedstock, especially because Indonesia is one of the main cassava producing countries in the world. (FAO, 2019) recorded a total production of $16,119,020$ ton cassava in 2018 with a total area of 697,384 ha, and productivity of 231,135 hg/ha, making Indonesia the sixth-largest cassava producing country in the world. Figure 1 visualized cassava production, along with area harvested and productivity in Indonesia since 1961 to 2018.

However, there is no study summarizing bioethanol potential from the whole cassava plant especially in Indonesia. Review and summary about current bioethanol potential from the whole cassava plant will provide a consideration to choose cassava as bioethanol feedstock in industrial scale, cheap bioethanol feedstock by utilizing the whole cassava plant to produce bioethanol, and therefore, increase the bioethanol yield per hectare area. Thus, this research was done to obtain bioethanol potential from the whole cassava plant and its processing waste, especially in Indonesia while considering other utilizations of cassava that may reduce availability of cassava as bioethanol feedstock.

\section{MATERIALS AND METHODS}

Calculation in this paper were made based on several data and parameters taken from different studies.

Table 1. Bioethanol potential from several crops (Wang, 2007)

\begin{tabular}{lccc}
\hline \multicolumn{1}{c}{ Crops } & $\begin{array}{c}\text { Productivity } \\
\text { (ton/ha/year) }\end{array}$ & $\begin{array}{c}\text { Conversion to Bioethanol } \\
\text { (liter/ton) }\end{array}$ & $\begin{array}{c}\text { Bioethanol Yield } \\
\text { (liter/ha/year) }\end{array}$ \\
\hline Cassava tuber & 40 & 150 & 6,000 \\
Sugar cane & 70 & 70 & 4,900 \\
Sweet sorghum & 35 & 80 & 2,800 \\
Rice & 5 & 450 & 2,250 \\
Corn & 5 & 410 & 2,050 \\
Wheat & 4 & 390 & 1,560 \\
\hline
\end{tabular}

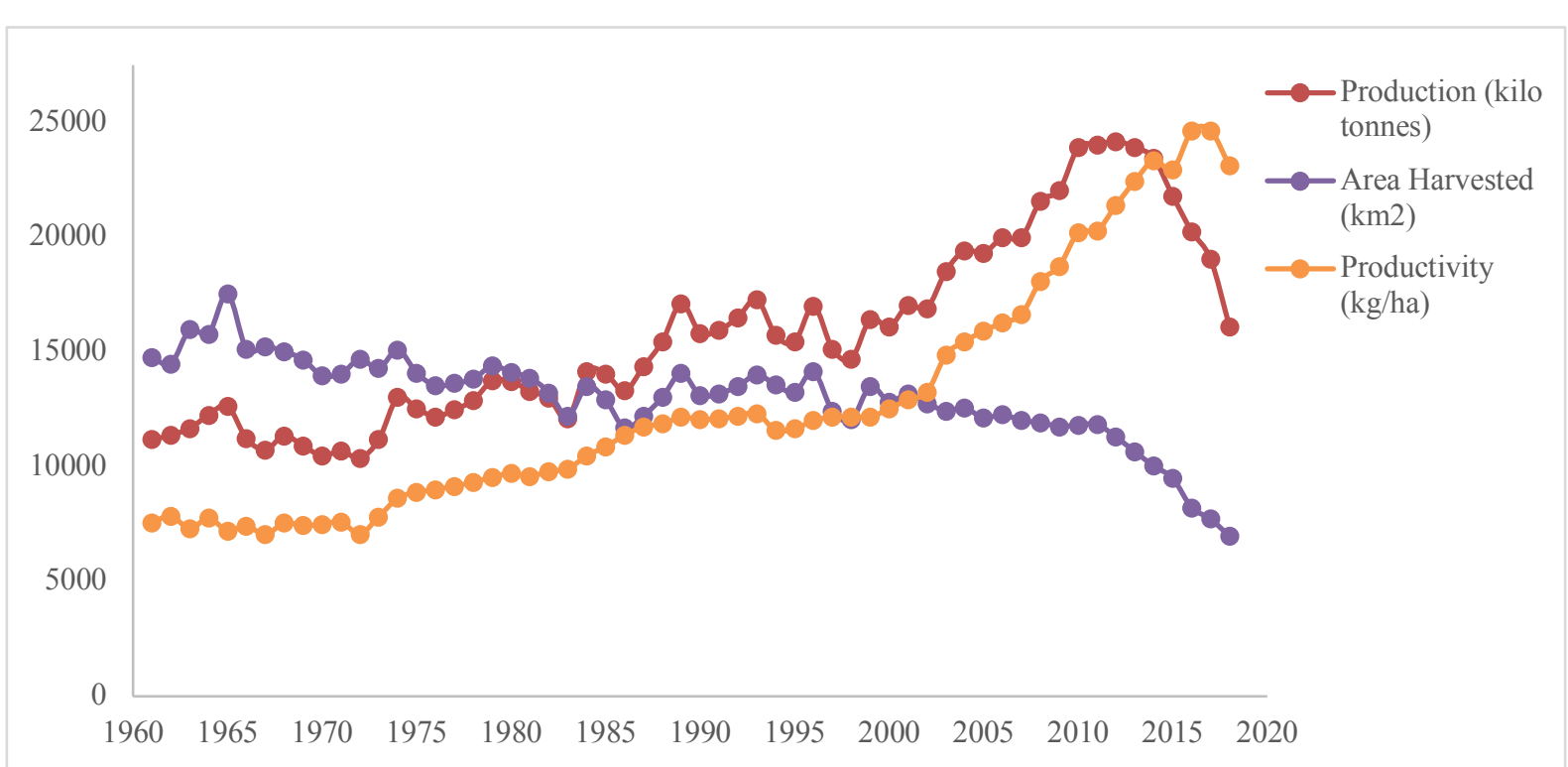

Figure 1. Production, area harvested, and productivity of cassava tuber in Indonesia (FAO, 2019) 


\section{Comparison of Bioethanol Yield from Several Studies}

Several studies about bioethanol from cassava tuber, stem, leaves, peel, and pile were collected and compared on the same basis. Bioethanol yield can be expressed in many ways, e.g. $\mathrm{mL}$ bioethanol/g substrate, $\mathrm{g}$ bioethanol/g substrate, $\mathrm{mL}$ bioethanol/L solution, $\mathrm{g}$ bioethanol/L solution, etc. To have a better comparison, the bioethanol yield unit was converted into the same unit. In this study, the unit was converted into L bioethanol/ton fresh substrate for cassava tuber, stem, leaves, peel; and L bioethanol/ton dry substrate for cassava pile with several assumptions listed below. The result was then compared with the study done by Wang (2007) which state that casava tuber has bioethanol yield of 150 L/ton.
Concentration of bioethanol in the unit of $\mathrm{g}$ bioethanol/L solution is converted into $\mathrm{L}$ bioethanol/ton substrate with the following equations $1-5$.

\section{Calculation of Bioethanol Potential from Whole Cassava Plant}

The average bioethanol yield from each part of the plant was then used to calculate bioethanol potential from the whole cassava plant by multiplying it with the mass proportion of the cassava plant. However, the mass of other parts than tuber is often not quantified, as cassava production data is expressed in terms of ton of tuber produced. Therefore, mass of other parts of the plant is calculated based on the mass percentage of the plant relative to the tuber.

$$
\begin{aligned}
\frac{g \text { bioethanol }}{1 \text { Liter final solution }}= & \frac{g \text { substrate }}{1 \text { Liter } \text { initial solution }} \ldots \ldots \ldots \\
\text { Bioethanol yield }= & \frac{g \text { bioethanol } \div 0.7893 \frac{g}{m L}}{g \text { substrate }} \ldots \ldots \\
& =\frac{m L \text { bioethanol } \div 1,000 \frac{m L}{L}}{g \text { substrate } \div 1,000,000 \frac{g}{t o n}} \ldots \\
& =\frac{L \text { bioethanol }}{\text { ton substrate }} \ldots \ldots \ldots \ldots \ldots
\end{aligned}
$$

\begin{tabular}{|c|c|c|c|}
\hline Process parameter & Value & Details & References \\
\hline Bioethanol density & $0.7893 \mathrm{~g} / \mathrm{mL}$ & Ethanol density at $20^{\circ} \mathrm{C}$ & - \\
\hline $\begin{array}{l}\text { Fresh cassava tuber to tapioca } \\
\text { starch convertion ratio }\end{array}$ & $0.225 \mathrm{w} / \mathrm{w}$ & $\begin{array}{l}\text { Starch content of the tuber } \\
25 \%\end{array}$ & $\begin{array}{l}\text { Lebot (2019); Yang, } \\
\text { El-Ensashy, and } \\
\text { Thongchul (2013) }\end{array}$ \\
\hline $\begin{array}{l}\text { Fresh cassava tuber to dry chips } \\
\text { or cassava flour conversion ratio }\end{array}$ & $0.4 \mathrm{w} / \mathrm{w}$ & $\begin{array}{l}\text { Drying to moisture content } \\
14 \%\end{array}$ & $\begin{array}{l}\text { Lebot (2019); Yang, } \\
\text { El-Ensashy, and } \\
\text { Thongchu }\end{array}$ \\
\hline $\begin{array}{l}\text { Fresh cassava stem to dry stem } \\
\text { conversion ratio }\end{array}$ & $0.4 \mathrm{w} / \mathrm{w}$ & $\begin{array}{l}\text { Drying to moisture content } \\
10 \%\end{array}$ & $\begin{array}{l}\text { Mohan et al. (2019); } \\
\text { Nuwamanya et al. } \\
(2012)\end{array}$ \\
\hline $\begin{array}{l}\text { Fresh cassava leaves to dry } \\
\text { leaves conversion ratio }\end{array}$ & $0.3 \mathrm{w} / \mathrm{w}$ & $\begin{array}{l}\text { Drying to moisture content } \\
10 \%\end{array}$ & $\begin{array}{l}\text { Mohan et al. (2019); } \\
\text { G. Ravindran and } \\
\text { Ravindran (1988) }\end{array}$ \\
\hline $\begin{array}{l}\text { Fresh cassava peel to dry peel } \\
\text { conversion ratio }\end{array}$ & $0.4 \mathrm{w} / \mathrm{w}$ & $\begin{array}{l}\text { Drying to moisture content } \\
10 \%\end{array}$ & $\begin{array}{l}\text { Nuwamanya et al. } \\
(2012) ; \quad \text { Santosa } \\
(2004)\end{array}$ \\
\hline $\begin{array}{l}\text { Final volume of fermentation } \\
\text { broth }\end{array}$ & $\begin{array}{l}\text { Initial volume of } \\
\text { the solution when } \\
\text { substrate was } \\
\text { prepared }\end{array}$ & $\begin{array}{l}\text { If the final volume of } \\
\text { fermentation broth was not } \\
\text { defined }\end{array}$ & - \\
\hline
\end{tabular}

Table 2. Parameter used for bioethanol yield convertion 
Ravindran (1993) studied that cassava plant consists of approximately $45 \%$ root, $35 \%$ stem, and $20 \%$ forage, while forage composed of $45 \%$ leaf, $25 \%$ petiole, and $30 \%$ tender stem. Fresh cassava tuber is comprised of 6-15\% fresh cassava peel (Grace, 1977; Sivamani and Baskar, 2015), and 10-15\% dry pile (Sriroth as cited in Sivamani et al., 2018; Thongkratok et al., 2010). To simplify the calculation, the cassava plant is assumed to be comprised of tuber, stem, and leaves with a mass percentage of $45 \%, 40 \%$, and $15 \%$, respectively. Cassava tuber is assumed to comprise $10 \%$ fresh peel, and $15 \%$ of dry pile.

\section{The Scenario of Cassava Plantation Conditions in Indonesia}

The scenario of cassava plantation conditions in Indonesia was made based on area harvested and productivity of cassava from 2010 to 2018. Area harvested of cassava is decreasing over the year, and the total area harvested in 2018 was 697,384 ha. From 2010 to 2018, the average cassava productivity was 22.6 ton $\mathrm{ha}^{-1}$ year ${ }^{-1}$, and the highest productivity was recorded in 2017 with a productivity of 24.6 ton/ha (FAO, 2019).

For the scenario of cassava plantation condition in Indonesia, the total area harvested is assumed to be 700,000 ha, nearly the same with area harvested in 2018, with cassava productivity of 22.5 ton/ha/year.

\section{The Scenario of Cassava Utilization in Indonesia}

Theoretically, it is possible to use all cassava and its plant for bioethanol production. However, it is not practical, especially in Indonesia where cassava is widely used for other utilizations. Some of the stems are used to vegetatively propagate the plant and the rest is assumed to be used for bioethanol production. All the leaves during harvesting are assumed to be used for bioethanol production. The peels and piles from cassava processing industries are also assumed used for bioethanol production.

\section{Tuber Utilization}

From 2010 to 2018, BPS recorded average cassava consumption in the household sector was $4.429 \mathrm{~kg} /$ capita/year (Pusat Data dan Sistem Informasi Pertanian 2012, 2015, 2018). However, Widianingsih (2016) argued that the SUSENAS result recorded by BPS-Statistics Indonesia was very low (underestimate), as this value only counted fresh cassava consumption in the household sector, while processed cassava both for food and non-food industry was not counted in the survey. Thus, this value should be added with processed cassava consumption.

Badan Pusat Statistik (2019) recorded that in 2018, Indonesia's population reached up to $265,015,300$ people with an average annual growth rate of $1.33 \%$ from 2010 to 2018 . With this data, it is assumed that total population in Indonesia is $272,000,000$, with consumption of fresh cassava tuber in the household sector $5 \mathrm{~kg} /$ capita/year, added with consumption of processed cassava from $20 \mathrm{~kg}$ tuber/capita/year, which is around 4 times of fresh cassava tuber consumption. Other than food consumption, the rest of the tuber is used for tapioca starch. Production of tapioca starch is assumed to produce cassava peel and pile that can be collected and reprocessed into bioethanol.

\section{Stem Utilization}

Zhu et al. (2015) mentioned that 10-20\% of cassava stem is used to vegetatively propagate the plant. For this scenario, it is assumed that $15 \%$ of the cassava stem is used to propagate the plant and the rest is used for bioethanol production.

\section{Leaves Utilization}

All the leaves during harvesting are assumed to be used for bioethanol production. Leaves for food consumption is assumed to be collected through pruning before the tuber is harvested, and pruning gives no negative effect on the productivity of the tuber.

\section{RESULT AND DISCUSSION}

\section{Bioethanol Yield from Several Studies}

Bioethanol yield from cassava tuber, stem, leaves, peel, and pile in several studies along with its average bioethanol yield are shown in Table 2 to 6 . The value was taken form experiment done in other studies, then converted into L bioethanol/ton fresh substrate. Although bioethanol yield usually expressed in the form of $\mathrm{g}$ bioethanol/g substrate, in this study, L bioethanol/fresh substrate was taken to compare the result obtained wih study done by Wang (2007) on Table 1, which stated that cassava tuber has bioethanol yield of $150 \mathrm{~L} / \mathrm{ton}$. To convert the bioethanol yield to $\mathrm{g}$ bioethanol/g substrate, $\mathrm{L}$ bioethanol/ton fresh substrate is multiplied with bioethanol density.

On average, fresh cassava tuber, stem, leaves, peel, and dry pile have bioethanol yield of $180 \mathrm{~L} / \mathrm{ton}$, $155 \mathrm{~L} /$ ton, $75 \mathrm{~L} /$ ton, $160 \mathrm{~L} /$ ton, and $390 \mathrm{~L} /$ ton, respectively. The average value is taken for further calculation even though the range of data obtained from literature is relatively wide. The reason for taking the average is that the data obtained from literature is ranging from lab scale to pilot scale processing. Further development to actual industrial scale generally have unknown effect to yield and coversion, incomparison to smaller scale. Taking average is considered reasonable approach in compensating the actual potential of yield in industrial scale in estimating the capacity of the technology. 
Table 3. Comparison of bioethanol yield from cassava tuber

\begin{tabular}{|c|c|c|c|}
\hline Author(s) & & Methods & $\begin{array}{c}\text { Equivalent Bioethanol } \\
\text { Yield* (L/ton fresh } \\
\text { tuber) } \\
\end{array}$ \\
\hline $\begin{array}{l}\text { Atthasampunna et al. } \\
\text { (1987) }\end{array}$ & \multirow[t]{2}{*}{$\begin{array}{l}\text { Enzymatic } \\
\text { hydrolysis }\end{array}$} & $\begin{array}{l}\text { Low-temperature processing } \\
\text { High-temperature processing }\end{array}$ & $185-200$ \\
\hline \multirow{3}{*}{ Ueda et al. (1981) } & & Commercial Aspergillus niger & 206.618 \\
\hline & \multirow{2}{*}{$\begin{array}{l}\text { Enzymatic } \\
\text { hydrolysis, SLSF }\end{array}$} & $\begin{array}{l}\text { Aspergillus awamori NRRL } \\
3112\end{array}$ & 199.544 \\
\hline & & $\begin{array}{l}\text { Aspergillus niger from } \\
\text { University of Kyushu }\end{array}$ & 190.042 \\
\hline \multirow[t]{2}{*}{$\begin{array}{l}\text { Yuwa-Amompitak } \\
(2010)\end{array}$} & \multicolumn{2}{|c|}{ Enzymatic hydrolysis using Rhizopus sp \#3Su, SSF } & 68.225 \\
\hline & \multirow{5}{*}{ Acid hydrolysis } & TMS 92B/00068 & 240 \\
\hline \multirow{4}{*}{$\begin{array}{l}\text { Ademiluyi and Mepba } \\
\text { (2013) }\end{array}$} & & TMS 91/02324 & 220 \\
\hline & & TMS 98/0581 & 204 \\
\hline & & TMS 92B/00061 & 200 \\
\hline & & TMS 98/0505 & 168 \\
\hline \multirow[t]{2}{*}{ Wangpor et al. (2017) } & \multicolumn{2}{|c|}{ Enzymatic hydrolysis } & 124.002 \\
\hline & \multicolumn{2}{|l|}{ Average } & 183.786 \\
\hline
\end{tabular}

Note: * (converted value from original finding)

Table 4. Comparison of bioethanol yield from cassava stem

\begin{tabular}{|c|c|c|c|}
\hline Author(s) & & Methods & $\begin{array}{l}\text { Equivalent Bioethanol } \\
\text { Yield* (L/ton fresh } \\
\text { stem) }\end{array}$ \\
\hline Han et al. (2011) & \multicolumn{2}{|c|}{ Acid pretreatment, enzymatic hydrolysis } & 95.654 \\
\hline $\begin{array}{l}\text { Nuwamanya et al. } \\
\text { (2012) }\end{array}$ & \multicolumn{2}{|c|}{ Chemical and enzymatic hydrolysis } & 104.8 \\
\hline \multirow{11}{*}{$\begin{array}{l}\text { Sovorawet and } \\
\text { Kongkiattikajorn } \\
(2012)\end{array}$} & \multirow{6}{*}{$\begin{array}{l}\text { Acid pretreatment, } \\
\text { enzymatic } \\
\text { hydrolysis, SHF }\end{array}$} & S. cerevisiae TISTR5048 & 201.698 \\
\hline & & S. cerevisiae KM1195 & 210.313 \\
\hline & & S. cerevisiae KM7253 & 199.164 \\
\hline & & Co-culture $S$. cerevisiae & \multirow{3}{*}{205.245} \\
\hline & & TISTR5048 and C. tropicalis & \\
\hline & & TISTR5045. & \\
\hline & \multirow{5}{*}{$\begin{array}{l}\text { Acid pretreatment, } \\
\text { enzymatic } \\
\text { hydrolysis, SSF }\end{array}$} & S. cerevisiae TISTR5048 & 182.440 \\
\hline & & S. cerevisiae KM1195 & 209.806 \\
\hline & & S. cerevisiae KM7253 & 188.015 \\
\hline & & Co-culture $S$. cerevisiae & \\
\hline & & $\begin{array}{l}\text { TISTR } 5048 \text { and C. tropicalis } \\
\text { TISTR5045. }\end{array}$ & 199.671 \\
\hline $\begin{array}{l}\text { Peláez, Alfaro, and } \\
\text { Montoya (2013) }\end{array}$ & \multicolumn{2}{|c|}{$\begin{array}{l}\text { Alkaline pretreatment, enzymatic hydrolysis derived } \\
\text { from Trichoderma reesei, SSF }\end{array}$} & 59.2 \\
\hline $\begin{array}{l}\text { Klinpratoom, Ontanee, } \\
\text { and Ruangviriyachai } \\
(2015)\end{array}$ & \multicolumn{2}{|c|}{$\begin{array}{l}2 \text { stage chemical pretreatment using } \mathrm{NaOCl}_{2} \text { and } \mathrm{NaOH} \text {, } \\
\text { acid hydrolysis }\end{array}$} & 114.404 \\
\hline Tanaka et al. (2019) & \multicolumn{2}{|c|}{2 step acid hydrolysis, intermittent inoculation } & 47.511 \\
\hline \multicolumn{3}{|c|}{ Average } & 155.227 \\
\hline
\end{tabular}


Table 5. Comparison of bioethanol yield from cassava leaves

\begin{tabular}{|c|c|c|c|}
\hline Author(s) & & Methods & $\begin{array}{l}\text { Equivalent Bioethanol } \\
\text { Yield* (L/ton fresh } \\
\text { leaves) }\end{array}$ \\
\hline \multirow{9}{*}{$\begin{array}{l}\text { Kongkiattikajorn } \\
(2011)\end{array}$} & \multirow{5}{*}{$\begin{array}{l}\text { Acid pretreatment, } \\
\text { enzymatic } \\
\text { hydrolysis, SHF }\end{array}$} & S. cerevisiae TISTR5048 & 83.238 \\
\hline & & S. cerevisiae KM1195 & 88.179 \\
\hline & & S. cerevisiae KM7253 & 76.397 \\
\hline & & Co-culture $S$. cerevisiae & \\
\hline & & $\begin{array}{l}\text { TISTR5048 and C. tropicalis } \\
\text { TISTR5045. }\end{array}$ & 84.759 \\
\hline & \multirow{4}{*}{$\begin{array}{l}\text { Acid pretreatment, } \\
\text { enzymatic } \\
\text { hydrolysis, SSF }\end{array}$} & S. cerevisiae TISTR5048 & 74.876 \\
\hline & & S. cerevisiae KM1195 & 90.080 \\
\hline & & S. cerevisiae KM7253 & 85.139 \\
\hline & & $\begin{array}{l}\text { Co-culture } S \text {. cerevisiae } \\
\text { TISTR5048 and } C \text {. tropicalis } \\
\text { TISTR } 5045 \text {. }\end{array}$ & 87.039 \\
\hline $\begin{array}{l}\text { Nuwamanya et al. } \\
\text { (2012) }\end{array}$ & \multicolumn{2}{|c|}{ Chemical and enzymatic hydrolysis } & 22.6 \\
\hline $\begin{array}{l}\text { Anbuselvi and } \\
\text { Balamurugan (2013) }\end{array}$ & \multicolumn{2}{|c|}{$\begin{array}{l}\text { Enzymatic hydrolysis using } \alpha \text {-amylase from barley } \\
\text { malt }\end{array}$} & 88.350 \\
\hline \multicolumn{3}{|c|}{ Average } & 78.066 \\
\hline
\end{tabular}

Note: * (converted value from original finding)

Table 6. Comparison of bioethanol yield from cassava peel

\begin{tabular}{|c|c|c|}
\hline Author(s) & Methods & $\begin{array}{l}\text { Equivalent Bioethanol } \\
\text { Yield* (L/ton fresh } \\
\text { peel) }\end{array}$ \\
\hline \multirow{3}{*}{$\begin{array}{l}\text { Akponah and Akpomie } \\
\text { (2011) }\end{array}$} & Acid hydrolysis using $\mathrm{H}_{2} \mathrm{SO}_{4} 0.6 \mathrm{M}$ & 175.2 \\
\hline & Enzymatic Aspergillus niger & 105 \\
\hline & $\alpha$-amylase & 40.7 \\
\hline \multirow{3}{*}{$\begin{array}{l}\text { Kongkiattikajorn and } \\
\text { Sornvoraweatn (2011) }\end{array}$} & S. diastaticus 2047 & 211.833 \\
\hline & Acid pretreatment, & 141.898 \\
\hline & $\begin{array}{l}\text { Co-culture of } S . \text { diastaticus } 2047 \\
\text { and C. tropicalis } 5045\end{array}$ & 223.489 \\
\hline Oyeleke et al. (2012) & $\begin{array}{l}\text { Enzymatic hydrolysis using } G \text {. sepiarium and } P \text {. } \\
\text { ostreatus and fermented using } Z \text {. mobilis and } S . \\
\text { cerevisiae }\end{array}$ & 298 \\
\hline Abidin et al. (2014) & Acid hydrolysis using $\mathrm{H}_{2} \mathrm{SO}_{4} 0.5 \mathrm{M}$ & 95.467 \\
\hline $\begin{array}{l}\text { Ezebuiro and Ogugbue } \\
\text { (2015) }\end{array}$ & $\begin{array}{l}\text { Acid hydrolysis, fermentation using VCE-19 Bacillus } \\
\text { cereus GBPS9 }\end{array}$ & 225.516 \\
\hline \multirow{2}{*}{$\begin{array}{l}\text { Efeovbokhan et al. } \\
\text { (2019) }\end{array}$} & \multirow{2}{*}{$\begin{array}{l}\text { Acid hydrolysis using } \mathrm{HCl} 0.7 \mathrm{M} \\
\text { Enzymatic hydrolysis using } A \text {. niger with heat } \\
\text { pretreatment }\end{array}$} & 168 \\
\hline & & 104 \\
\hline
\end{tabular}

Note: * (converted value from original finding)

\section{Bioethanol Potential from Whole Cassava Plant}

Bioethanol yield from whole cassava plant along with its processing waste is calculated by multiplying the average bioethanol yield with the mass of each part of the cassava plant. In general, bioethanol yield can be calculated as follows.

However, since cassava production data is expressed in terms of ton of tuber produced, the mass of other parts of the plant is often not quantified. In this study, cassava plant is assumed to be comprised of tuber, stem, and leaves with a mass percentage of $45 \%, 40 \%$, and $15 \%$, respectively. Cassava tuber is assumed to comprise $10 \%$ fresh peel, and $15 \%$ dry pile.

Equation 7 to 11 can be substituted to equation 5 , and the bioethanol yield from the whole cassava plant along with its processing waste can be calculated as follows. 
Table 7. Comparison of bioethanol yield from cassava pile

\begin{tabular}{|c|c|c|c|}
\hline Author(s) & & Methods & $\begin{array}{l}\text { Equivalent Bioethanol } \\
\text { Yield* (L/ton dry pile) }\end{array}$ \\
\hline \multirow[t]{2}{*}{ Kosugi et al. (2009) } & \multirow[t]{2}{*}{$\begin{array}{l}\text { Hydrothermal, acid } \\
\text { pretreatment }\end{array}$} & $\begin{array}{l}\text { Enzymatic hydrolysis } \\
\text { (cellulase), fermentation } S \text {. } \\
\text { cerevisiae } \mathrm{K} 7 \mathrm{G} \\
\text { Enzymatic hydrolysis (cellulase, } \\
\alpha \text {-amylase, glucoamylase), } \\
\text { fermentation } S \text {. cerevisiae K7 }\end{array}$ & 471.304 \\
\hline & & C. thermocellum ATCC 27405 & 225.516 \\
\hline \multirow[t]{2}{*}{ Li and Zhu (2011) } & \multirow{2}{*}{$\begin{array}{l}\text { Enzymatic } \\
\text { hydrolysis }\end{array}$} & $\begin{array}{l}\text { T. aotearoense SCUT27 } \\
\text { Co-culture } C \text {. thermocellum }\end{array}$ & 250.538 \\
\hline & & $\begin{array}{l}\text { ATCC } 27405 \text { and T. aotearoense } \\
\text { SCUT27 }\end{array}$ & 281.579 \\
\hline \multirow[t]{2}{*}{ Ndubuisi et al. (2018) } & \multicolumn{2}{|c|}{ Enzymatic hydrolysis using Pichia kudriavzevii } & 266.059 \\
\hline & \multirow{4}{*}{$\begin{array}{l}\text { Enzymatic } \\
\text { hydrolysis }\end{array}$} & Sample A1 & 103.48 \\
\hline \multirow{3}{*}{ Martinez et al. (2018) } & & Sample A2 & 368.21 \\
\hline & & Sample A3 & 97.49 \\
\hline & & Sample A4 & 461.39 \\
\hline \multirow{6}{*}{$\begin{array}{l}\text { Efeovbokhan et al. } \\
\text { (2019) }\end{array}$} & \multirow{3}{*}{ Acid hydrolysis } & IBA980505 & 415 \\
\hline & & IBA950289 & 695 \\
\hline & & IBA010040 & 470 \\
\hline & \multirow{3}{*}{$\begin{array}{l}\text { Enzymatic } \\
\text { hydrolysis using } A \text {. } \\
\text { niger with heat } \\
\text { pretreatment }\end{array}$} & IBA980505 & 490 \\
\hline & & IBA950289 & 725 \\
\hline & & IBA010040 & 540 \\
\hline & Average & & 393.050 \\
\hline
\end{tabular}

Note: * (converted value from original finding)

Bioethanol yield from whole cassava plant

$$
\begin{aligned}
& =\left(\text { mass of fresh tuber without peel } \times 180 \frac{L}{\text { ton }}\right) \\
& +\left(\text { mass of fresh stem } \times 155 \frac{L}{\text { ton }}\right) \\
& +\left(\text { mass of fresh leaves } \times 75 \frac{L}{\text { ton }}\right) \\
& +\left(\text { mass of fresh peel } \times 160 \frac{L}{\text { ton }}\right) \\
& +\left(\text { mass of dry bagasse } \times 390 \frac{L}{\text { ton }}\right)
\end{aligned}
$$

If $m=$ mass of fresh tuber harvested

- mass of fresh tuber without peel $=0.9 \mathrm{~m}$

mass of fresh stem $=\frac{0.4}{0.45} \mathrm{~m}$

mass of fresh leaves $=\frac{0.15}{0.45} \mathrm{~m}$

- mass of fresh peel $=0.1 \mathrm{~m}$

- mass of dry bagasse $=0.15 \mathrm{~m}$ 


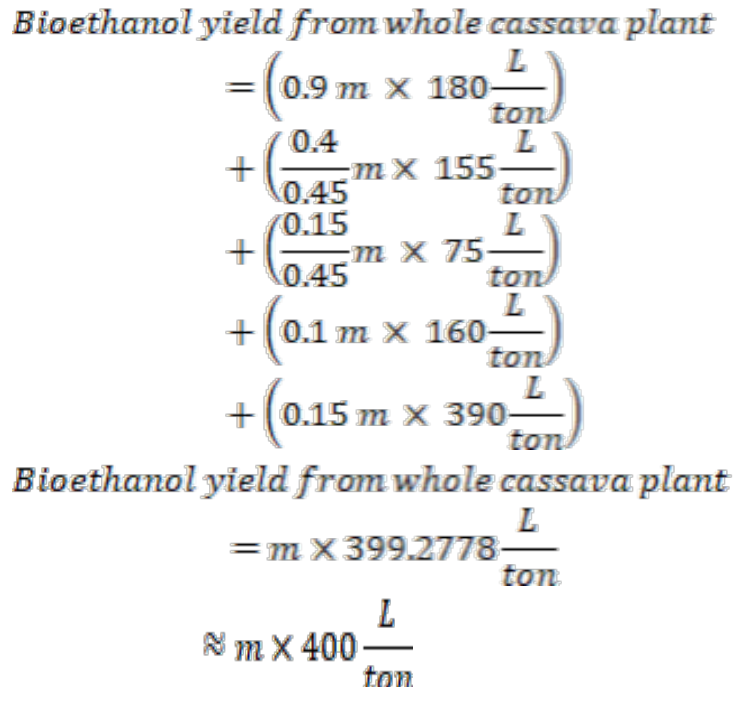

Generally, cassava tuber is peeled before it is processed into bioethanol, therefore only $90 \%$ of the tuber mass is multiplied with average bioethanol yield $180 \mathrm{~L} /$ ton. The rest $10 \%$ is cassava peel and multiplied with average bioethanol yield of $160 \mathrm{~L} / \mathrm{ton}$. If processing cassava tuber into bioethanol were assumed to produce $15 \%$ dry pile that can be reprocessed into bioethanol through lignocellulosic hydrolysis and fermentation, an additional $390 \mathrm{~L}$ bioethanol can be produced from a ton of dry pile. From those average bioethanol yield and mass percentage assumptions, if the whole cassava plant along with its processing waste were utilized for bioethanol production, it can be predicted that cassava plants that produce a ton of cassava tuber can yield 399.28 L bioethanol or nearly $400 \mathrm{~L}$ bioethanol.

However, if the pile were not reprocessed into bioethanol, the bioethanol yield from whole cassava plant is reduced into $340 \mathrm{~L}$ and calculated as follow (Equation 14 and 15).

Whether pile is reprocessed into bioethanol or not, both bioethanol potentials are higher and significant compared to only processing cassava tuber, which based on this study yield to $180 \mathrm{~L}$ bioethanol/ton and based on Rao (as cited in Wang, 2007 ) yield to $150 \mathrm{~L} /$ ton. Utilizing the whole cassava plant as bioethanol feedstock produces approximately 2 times higher bioethanol yield compared to only processing cassava tuber. Thus, it is advantageous to utilize all parts of the cassava plant and its processing waste as bioethanol feedstock. Especially because cassava is harvested as an annual crop, in which the plant is harvested by uprooting the plant. Thus, during harvesting, all parts of the cassava plant are also harvested, and it produces a lot of biomass that if not utilized and treated well will become merely agricultural waste. Instead of becoming agricultural waste, the biomass can be used for bioethanol production.

However, further study should be done to investigate the economic feasibility of the overall process. Processing the whole cassava plant using different methods for each part of the plant will lead to many different processes, which require a lot of equipment and may increase the initial capital cost. Furthermore, study conducted by Mcaloon et al. (2000) showed that generally, bioethanol from lignocellulosic feedstock is more expensive than bioethanol from starch feedstock (corn). The highest cost contributor in bioethanol from lignocellulosic feedstock is the depreciation of capital cost which includes the equipment such as reactor tanks, whereas the highest cost contributor in bioethanol from starch feedstock is the feedstock itself.

Other than economic feasibility, net energy gain (NEG) of the process should also be investigated. Currently, distillation is the highest energy consumption in bioethanol production, which based on Lee and Pahl (1985) conventional distillation accounts for $50-80 \%$ of the energy input. Although many studies have calculated a positive net energy gain from cassava (Cheroennet and Suwanmanee, 2017; Gallegos et al., 2014; Hanif et al., 2017), with further development in distillation technology and other bioethanol production processes, energy input or on-site energy demand for bioethanol production can be reduced, and therefore increase the net energy gain from cassava and its plant.

With suitable methods, cassava stem, peel, and pile have comparable bioethanol yield with the tuber, where based on the average value, the bioethanol yields are $155 \mathrm{~L} /$ ton fresh stem, $160 \mathrm{~L} /$ ton fresh peel, and $390 \mathrm{~L} /$ ton dry pile, compared to $180 \mathrm{~L} /$ ton fresh tuber without peel. Cassava leaves have lower potential compared to other parts of the plant, where it produces only $75 \mathrm{~L}$ bioethanol/ton fresh leaves. Sivamani et al. (2018) mentioned that cassava leaves have lower bioethanol potential compared to other parts of the plant due to low carbohydrate and high protein content.

Wang et al. (2008) mentioned that starch and protein have an inverse relationship in a unit mass of grain, thus as protein increases, carbohydrate and 
bioethanol yield usually decrease. Additionally, small starch granules can be embedded in protein matrix, thus became ungelatinized during cooking and inaccessible to hydrolytic means.

Considering the average bioethanol yield and the mass proportion of each part relative to the fresh tuber, fresh tuber without peel contributes to the highest bioethanol yield as it has the biggest mass percentage and high bioethanol yield of $180 \mathrm{~L} / \mathrm{ton}$. Figure 2 shows the mass proportion of other parts of the plant relative to the fresh tuber, and Figure 3 shows the bioethanol yield from each part based on the baker's percentage on fresh tuber mass.

\section{Bioethanol yield from whole cassava plant without bagasse}

$$
\begin{aligned}
& =\left(0.9 m \times 180 \frac{L}{\text { ton }}\right) \\
& +\left(\frac{0.4}{0.45} m \times 155 \frac{L}{\text { ton }}\right) \\
& +\left(\frac{0.15}{0.45} m \times 75 \frac{L}{\text { ton }}\right) \\
& +\left(0.1 m \times 160 \frac{L}{\text { ton }}\right)
\end{aligned}
$$

Bioethanol yield from whole cassava plant without bagasse

$$
\begin{gathered}
=m \times 340.7778 \frac{L}{\text { ton }} \\
\approx m \times 340 \frac{L}{\text { ton }}
\end{gathered}
$$

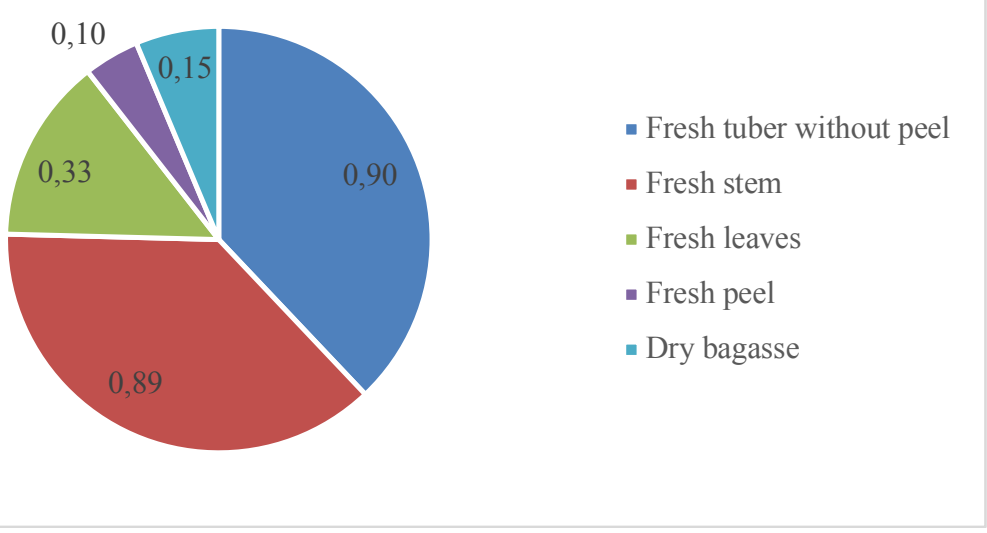

Figure 2. Mass proportion of parts of plant relative to fresh cassava tuber $(\mathrm{kg} / \mathrm{kg}$ fresh tuber)

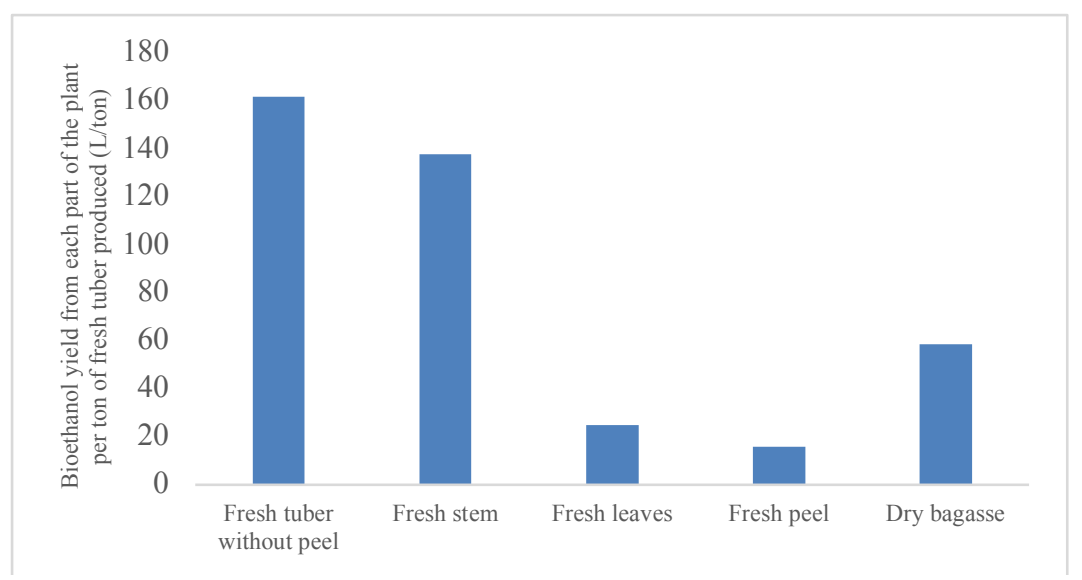

Figure 3. Bioethanol yield based on the mass proportion of other parts of the plant relative to fresh cassava tuber 
Next to fresh tuber without peel, fresh stem contributes to the second-highest bioethanol yield because it has the biggest mass percentage after cassava tuber and high bioethanol yield of $155 \mathrm{~L} / \mathrm{ton}$. Fresh cassava peel contributes the least because it has the lowest mass percentage, accounts for only $10 \%$ of the tuber mass. Relative to the tuber, the fresh leaves have a bigger mass proportion compared to dry pile, however, the leaves have lower contribution because it has low bioethanol potential of $75 \mathrm{~L} /$ ton. Dry pile has higher contribution because it has a higher bioethanol yield of $390 \mathrm{~L} / \mathrm{ton}$.

\section{Bioethanol Potential from Whole Cassava Plant in Indonesia}

With a scenario of total area harvested 700,000 ha and cassava productivity of 22.5 ton $^{-1} \mathrm{year}^{-1}$, the total production of cassava tuber in Indonesia is $15,750,000$ ton per year. The total area harvested was chosen based on the area harvested in 2018, and the productivity was chosen based on the average productivity from 2010 to 2018 .

Over the year, the area harvested of cassava shows a declining trend with the latest data in 2018 of 697,384 ha (FAO, 2019). It is predicted that the decline in the area harvested is related to the low selling price of the cassava. With a better price and technology, it is expected that the total area harvested will increase and consequently fulfill the domestic needs. Especially considering that the demand for cassava in Indonesia is very high, while cassava production is currently not yet able to fulfill the domestic needs, and Indonesia still has to import cassava (especially in form of starch).

On the other hand, although cassava productivity is fluctuating, it shows an increasing trend with the highest productivity was recorded in 2017 with a value of 24.65 ton/ha. From 2010 to 2018, the average productivity was 22.56 ton/ha/year (FAO, 2019). However, the average productivity of cassava in Indonesia is relatively quite low compared with the productivity that mentioned by Rao (as cited in Wang, 2007), where the productivity of cassava was mentioned to be 40 ton/ha/year. This is because cassava productivity in several provinces is very low, for example in 2013, although the productivity in Sumatra Barat was 39.766 ton/ha, the productivity in Nusa Tenggara Timur was only 10.25 ton/ha, in
Papua Barat was 11.29 ton/ha, and in Kepulauan Riau was 11.93 ton/ha (Badan Pusat Statistik n.d.). To increase cassava productivity in Indonesia, the productivity in all the provinces should also be increased by planting the cassava in proper condition and choosing variety with high productivity.

With a total production of cassava tuber $15,750,000$ ton/year, the mass of the whole cassava plant produced is 35,000,000 ton/year. Table 7 shows the detailed biomass along with bioethanol that can be produced. If all the plants along with the additional dry pile were used for bioethanol production, approximately 6.3 billion L of bioethanol/year can be produced.

However, the bioethanol potential of 6.3 billion L/year is not feasible, as it is impossible and impractical to use all the cassava and its plant for bioethanol production. Furthermore, the actual applications of cassava in Indonesia are not for bioethanol production. Cassava tuber is widely used for other utilizations such as food and other processed industry such as tapioca starch, tapai, chips, and many others. The demand for cassava tuber is very high, and with the current production condition, it is almost impossible to use tuber as bioethanol feedstock. People would prefer to process cassava into food and other processed industry because it has a better price compared to bioethanol feedstock. Other than cassava tuber, cassava stem is utilized to propagate the plant and young cassava leaves are widely eaten as food and feed due to its high protein content. Cassava peel and pile are sometimes used as feed. Other utilization of cassava should be taken into account as it limits and reduces the availability of cassava as bioethanol feedstock, and thus reduce the bioethanol potential in Indonesia.

In the scenario, it is assumed that all cassava tubers are used for either food consumption or raw material for tapioca starch. The scenario was chosen based on the fact that Indonesia still has to import a large amount of cassava, especially in the form of starch. Table 8 shows the data of total imported cassava, imported cassava starch, and total exported cassava from 2014 to 2018 in Indonesia. Exported cassava is relatively small compared to the imported cassava, and for the scenario, it is assumed that all cassava tubers produced are used to fulfill the domestic needs.

Table 8. Biomass and bioethanol potential from whole cassava plant in Indonesia

\begin{tabular}{lcc}
\hline \multicolumn{1}{c}{ Parts of the plant } & $\begin{array}{c}\text { Biomass potential } \\
\text { (ton/year) }\end{array}$ & $\begin{array}{c}\text { Bioethanol potential } \\
\text { (liter/year) }\end{array}$ \\
\hline Fresh tuber without peel & $14,175,000$ & $2,551,500,000$ \\
Fresh stem & $14,000,000$ & $2,170,000,000$ \\
Fresh leaves & $5,250,000$ & $393,750,000$ \\
Fresh peel & $1,575,000$ & $252,000,000$ \\
Dry pile & $2,362,500$ & $921,375,000$ \\
\hline
\end{tabular}


Table 9. Exported and imported cassava from 2014 to 2018 in Indonesia (Badan Pusat Statistik n.d.)

\begin{tabular}{cccc}
\hline Year & Total exported cassava $\mathbf{( k g )}$ & $\begin{array}{c}\text { Total imported cassava } \\
(\mathbf{k g})\end{array}$ & $\begin{array}{c}\text { Cassava starch imported } \\
(\mathbf{k g})\end{array}$ \\
\hline 2014 & $114,500,682.00$ & $365,084,956.00$ & $365,084,956.00$ \\
2015 & $16,775,829.20$ & $600,163,056.00$ & $595,951,315.00$ \\
2016 & $47,875,846.00$ & $642,667,224.00$ & $630,126,574.00$ \\
2017 & $21,525,152.70$ & $388,821,935.00$ & $385,430,814.00$ \\
2018 & $10,703,937.40$ & $375,590,486.00$ & $375,589,316.00$ \\
\hline
\end{tabular}

For food consumption of cassava tuber in the household sector, it is assumed that the consumption of fresh cassava tuber is $5 \mathrm{~kg} /$ capita/year, and the consumption of processed cassava is $20 \mathrm{~kg}$ tuber/capita/year. The value was chosen based on the average of cassava consumption in the household sector from 2010 to 2018 which was recorded through a National Survey of Socio-Economics (SUSENAS) done by BPS.

Cassava consumption in the household sector from 2010 to 2018 was ranging from 3.422 to 6.355 $\mathrm{kg} /$ capita/year with an average value of 4.429 $\mathrm{kg}$ /capita/year (Pusat Data dan Sistem Informasi Pertanian 2012, 2015, 2018). Although cassava consumption in the household sector is fluctuating, it generally shows a declining trend. Center for Agricultural Data and Information System (as cited in Widianingsih, 2016) predicted that the consumption of $12.78 \mathrm{~kg} /$ capita in 1993 will decreases to only 2.15 $\mathrm{kg} /$ capita in 2020. As Widianingsih (2016) argued that the value only shows fresh cassava consumption in the household sector, it implies that the consumption of fresh cassava tuber as a staple food is reduced and replaced by other food. Nowadays, processed cassava are more preferable compared to fresh cassava, especially because fresh cassava is highly perishable.

Based on the argument by Widianingsih (2016) that stated SUSENAS result was very low (underestimate) and it only counted fresh cassava consumption in the household sector, the assumption of fresh cassava consumption $5 \mathrm{~kg} /$ capita/year should be added with the processed cassava consumption. It is assumed that the consumption of processed cassava in the household sector that includes tapai, gaplek, and cassava chips is made from $20 \mathrm{~kg}$ tuber/capita/year. In total, it is assumed that the food consumption of cassava is $25 \mathrm{~kg} / \mathrm{capita} /$ year, and with the assumption that the total population in Indonesia is $272,000,000$ people, cassava tuber consumption for food in the household sector is $6,800,000$ ton/year. The rest $8,950,000$ ton of the tuber per year are assumed to be used in industry for starch extraction.

In the household sector, fresh cassava consumption and processing into tapai, gaplek, cassava chips produce peel as its waste. However, the peel from fresh cassava consumption and processing cassava in the household sector is assumed cannot be collected for bioethanol production as it is distributed in every household in a small amount. On the other hand, processing cassava into tapioca starch is assumed to be done on a bigger scale and the waste that includes peel and pile can be collected for bioethanol production. Thus from the extraction of $8,950,000$ ton of fresh tuber per year, as much as 895,000 ton of fresh peel and 1,342,500 ton of dry pile can be collected for bioethanol production. From it, the peels can yield 143,200,000 L bioethanol, and the dry pile can yield 523,575,000 L bioethanol.

For cassava stem, it is assumed that from $14,000,000$ ton of cassava stems/year, $15 \%$ of it or equals to 2,100,000 ton/year are used to vegetatively propagate the plant. Other utilization of the stem such as firewood is neglected, as it is not significant and uneconomical. The rest 11,900,000 ton/year are assumed to be used in bioethanol production. From it, $1,844,500,000 \mathrm{~L}$ bioethanol/year can be produced. The stem has high potential as bioethanol feedstock, as it has a high mass percentage (accounts for $40 \%$ of the plant) and high bioethanol yield of $155 \mathrm{~L} /$ ton fresh stem. Furthermore, other than used to propagate the plant, the stem has no significant competitive utilization.

For the leaves, it is assumed that all the fresh leaves produced during harvesting are used for bioethanol production. Leaves for food and feed consumption is assumed to be collected from pruning, done before the tuber is harvested. Sivamani et al. (2018) mentioned that pruning is done to remove unwanted leaves and it enhance the tuber production. Morgan and Choct (2016) mentioned that every hectare of cassava planting can produce up to 10 ton of dry cassava leaves. This value is very big compared to the mass of the leaves collected during harvesting. With the assumption that leaves account for $15 \%$ of the plant and a hectare of an area harvested can yield a maximum of 40 ton of cassava tuber, the fresh leaves produced are only 13.333 ton or it equals to 4 ton of dry leaves. The value mentioned by Morgan and Choct (2016) is predicted to include the leaves from pruning. Thus, from proper pruning, additional 6 ton of dry leaves or 20 ton of fresh leaves can be collected. Therefore, all the 5,250,000 ton of fresh leaves collected during harvesting can be used for bioethanol production, and from it, approximately $393,750,000$ L of bioethanol per year can be produced. 
Table 10. Summary of the bioethanol potential from the whole cassava plant in Indonesia before and after considering other utilization of cassava

\begin{tabular}{lcccc}
\hline \multirow{2}{*}{ Parts of the plant } & \multicolumn{2}{c}{ Utilizing the whole cassava plant } & \multicolumn{2}{c}{$\begin{array}{c}\text { Considering other utilization of } \\
\text { cassava }\end{array}$} \\
\cline { 2 - 5 } & $\begin{array}{c}\text { Biomass } \\
\text { potential } \\
\text { (ton/year) }\end{array}$ & $\begin{array}{c}\text { Bioethanol } \\
\text { potential } \\
\text { (liter/year) }\end{array}$ & $\begin{array}{c}\text { Biomass } \\
\text { potential } \\
\text { (ton/year) }\end{array}$ & $\begin{array}{c}\text { Bioethanol } \\
\text { potential } \\
\text { (liter/year) }\end{array}$ \\
\hline Tuber without peel & $14,175,000$ & $2,551,500,000$ & - & - \\
Stem & $14,000,000$ & $2,170,000,000$ & $11,900,000$ & $1,844,500,000$ \\
Leaves & $5,250,000$ & $393,750,000$ & $5,250,000$ & $393,750,000$ \\
Peel & $1,575,000$ & $252,000,000$ & 895,000 & $143,200,000$ \\
Dry pile & $2,362,500$ & $921,375,000$ & $1,342,500$ & $523,575,000$ \\
\hline \multicolumn{1}{c}{ Total } & $\mathbf{3 7 , 3 6 2 , 5 0 0}$ & $\mathbf{6 , 2 8 8 , 6 2 5 , 0 0 0}$ & $\mathbf{1 9 , 3 8 7 , 5 0 0}$ & $\mathbf{2 , 9 0 5 , 0 2 5 , 0 0 0}$ \\
\hline
\end{tabular}

Table 9 shows the summary and illustration of the bioethanol potential from the whole cassava plant in Indonesia considering other utilization of cassava, based on the scenario and assumptions mentioned above. Theoretically, it is possible to use all the $35,000,000$ ton plants/year along with the additional $2,362,500$ ton dry pile/year for bioethanol production, where it will yield to approximately 6.3 billion $\mathrm{L}$ of bioethanol/year. However, it is impractical to use all the cassava and its plant for bioethanol production, especially in Indonesia where cassava is widely utilized for food and other processed industry such as tapioca starch. Considering other utilization of cassava, it is summed that Indonesia can produce 2.9 billion L bioethanol/year from unused cassava stem, leaves, peel, and pile. It is smaller compared to 6.3 billion L bioethanol/year, but the value of 2.9 billion is more feasible and practical to implement.

The value chosen in this scenario can differ with the real conditions as cassava plantation conditions and utilization in Indonesia changes. However, this scenario gives an illustration that bioethanol from other parts of cassava plant such as stem, leaves along with cassava processing waste such as peel and pile is significant compared to only processing cassava tuber. Even when all the tuber is used for other utilization, such as for food and industry, the amount of bioethanol produced from the unused stem, leaves, peel, and pile is still significant and worth considering.

\section{CONCLUSIONS AND RECOMENDATIONS}

\section{Conclusions}

Bioethanol from other parts of the cassava plant, such as stem and leaves, along with cassava processing waste such as peel and pile are significant to increase the total bioethanol potential from the whole cassava plant. If the whole cassava plant along with its processing waste were utilized to produce bioethanol, cassava plants that produce a ton of cassava tuber can yield $400 \mathrm{~L}$ bioethanol. It is significant compared to only processing a ton of cassava tuber that on average will yield to $180 \mathrm{~L}$ bioethanol.
Theoretically, all cassava plants can be used as bioethanol feedstock. With a scenario of total area harvested 700,000 ha and cassava productivity of 22.5 ton/ha/year, bioethanol potential from whole parts of cassava plant and its processing waste in Indonesia is 6.3 billion L/year. Considering other utilization of cassava, the bioethanol potential becomes 2.9 billion L/year. Even when the tuber is used for other utilization, the amount of bioethanol produced from the unused stem, leaves, peel, and pile is still significant and worth considering.

\section{Recomendations}

More research should be conducted to find a suitable method to produce high bioethanol yield from cassava plants and its waste, especially on cassava leaves because there are only a few studies about it.

The method produces the highest bioethanol yield should be up scaled to give more accurate bioethanol yield. Then, further studies about the economic feasibility cost and net energy gain of the process should also be done.

\section{REFERENCES}

Abidin Z, Ellena S, and Tadjuddin N. 2014. Bioethanol production from waste of the cassava peel (manihot esculenta) by acid hydrolysis and fermentation process. International Journal. PharmTech Research 6(4): 1209-12.

Ademiluyi FT and Mepba HD. 2013. Yield and properties of ethanol biofuel produced from different whole cassava flours. ISRN Biotechnology. 2013(40): 1-6.

Akponah E, Akpomie OO, Akponah OO, Akpomie EA. 2011. Analysis of the suitability of yam, potato and cassava root peels for bioethanol production using saccharomyces cerevisae. International Research Journal Microbiology. 2 : 393-98.

Anbuselvi S and Balamurugan T. 2013. Study on ethanol production from cassava leaves and pulp using s. cerevisiae. Research Journal Pharmaceutical, Biological and Chemical 
Sciences 4(2): 1755-61.

Atthasampunna P, Somchai P, Eur-aree A, Artjariyasripong S. 1987. Production of fuel ethanol from cassava. MIRCEN Journal Applied Microbiology and Biotechnology 3(2): 135-42.

Badan Pusat Statistik. "EXPORT DAN IMPORT." https://www.bps.go.id/exim/ (June 9, 2020a).

-. "Produksi Ubi Kayu Menurut Provinsi (Ton), 1993-2015." https:/www.bps.go.id/linkTableDinamis/view/ $\mathrm{id} / 880$ (June 8, 2020b).

Baeyens J, Kang Q, Appel L, Dewil R, Yongqin L, Tan T. 2015. Challenges and opportunities in improving the production of bio-ethanol. Progress in Energy and Combustion Science 47: 60-88.

Cheroennet $\mathrm{N}$ and Unchalee S. 2017. Net energy gain and water footprint of corn ethanol production in Thailand. Energy Procedia 118: 15-20.

Ezebuiro V and Chimezie JO. 2015. Bioethanol production by an ethanol-tolerant bacillus cereus strain gbps9 using sugarcane bagasse and cassava peels as feedstocks. Journal Biotechnology \& Biomaterials 05(04).

Food and Agriculture Organization of the United Nations (FAO). 2019. FAOSTAT Statistical Database. http://www.fao.org/faostat/en/\#data.

Gallegos RK, Delfin B, Suministrado C, Jessie CE, Marilyn ME. 2014. Energy analysis of cassava bioethanol production in the Philippines. Journal Japan Institute of Energy 93(3): 3019.

Grace MR. 1977. Cassava Processing. Food and Agriculture Organization of the United Nations Rome.

Liesbetini H, Khaswar S, Anya M, Ahmad JM. 2014. Produksi bioetanol dari hidrolisat pati singkong racun dengan fermentasi repeated-batch oleh saccharomyces cerevisiae terimobilisasi pada ampas singkong. Jurnal Teknologi Industri Pertanian 24(1): 20-27.

Han M, Kim Y, Kim Y, Chung B, Gi-Wook C. 2011. Bioethanol production from optimized pretreatment of cassava stem. Korean Journal of Chemical Engineering 28(1): 119-25.

Hanif M, Mahlia TMI, Aditiya HB, Abu Bakar MS. 2017. Energy and environmental assessments of bioethanol production from sri kanji 1 cassava in Malaysia. Biofuel Research Journal 4(1): 537-44.

Klinpratoom B, Anissara O, and Chalerm R. 2015. Improvement of cassava stem hydrolysis by two-stage chemical pretreatment for high yield cellulosic ethanol production." Korean Journal of Chemical Engineering 32(3): 413-23.

Kongkiattikajorn J. 2011. Comparison of bioproduction of ethanol in SHF and SSF from cassava leaves." In 49. Kasetsart University Annual Conference, Bangkok (Thailand), 1-4
Feb 2011.

Kongkiattikajorn J and Buddhiporn S. 2011. Comparative study of bioethanol production from cassava peels by monoculture and coculture of yeast jirasak. Kasetsart Journal Natural Science 45(2): 268-74.

Kosugi A, Kondo A, Ueda M, Murata Y, Vaithanomsat P, Thanapase M, Arai T,. Moria Y. 2009. Production of ethanol from cassava pulp via fermentation with a surface-engineered yeast strain displaying glucoamylase." Renewable Energy 34(5): 1354-58.

Lebot V. 2019. Tropical Root and Tuber Crops. 2nd ed. Cabi.

Lee FM and Robert HP. 1985. Solvent Screening study and conceptual extractive distillation process to produce anhydrous ethanol from fermentation broth." Industrial \& Engineering Chemistry Process Design and Development 24(1): 168-72.

Li P and Mingjun Z. 2011. A consolidated bioprocessing of ethanol from cassava pulp accompanied by hydrogen production." Bioresource Technology 102(22): 10471-79.

Martinez DG, Armin F, Reinaldo B, Katya R, Freitas Z. 2018. Ethanol production from waste of cassava processing. Applied Sciences (Switzerland) 8(11): 1-8.

Mcaloon A, Taylor F, Yee W. 2000. Determining the cost of producing ethanol from corn starch and lignocellulosic feedstocks determining the cost of producing ethanol from corn starch and lignocellulosic. Agriculture (October): 44. http:/www.ncbi.nlm.nih.gov/entrez/query.fcgi ? $\mathrm{cmd}=$ Retrieve $\& \mathrm{db}=$ PubMed\&dopt $=$ Citation \&list_uids $=7746742$.

Mohan G, Raju J, Shiny R, Abhilash PV, Soumya S., Sheela MN, Byju G. 2019. Biochemical, mineral and proximate composition of indian cassava varieties biochemical, mineral and proximate composition of indian cassava varieties 7(January): 1059-65.

Morgan NK and Mingan C. 2016. Cassava: Nutrient Composition and Nutritive Value in Poultry Diets. Animal Nutrition 2(4): 253-61. 0.

Ndubuisi I, Nweze JE, Onoyima NJ, Yoshinori M, Ogbonna1 JC. 2018. Ethanol production from cassava pulp by a newly isolated thermotolerant pichia kudriavzevii LC375240." Energy and Power Engineering. 10(10): 457-74.

Nuwamanya E, Chiwona K. Kawuki LRS, Baguma Y. 2012. Bio-Ethanol production from nonfood parts of cassava (Manihot esculenta Crantz)." Ambio 41(3): 262-70.

Oyeleke S, Dauda B, Oyewole OA, Okoliegbe LN, Ojebode T. 2012. Production of Bioethanol from cassava and sweet potato peels. Advances in Environmental Biology 6(1): 241-45.

Peláez HC, Juan RA, and José ZM. 2013. 
Simultaneous Saccharification and Fermentation of Cassava Stems. DYNA (Colombia) 80(180): 97-104.

Pusat Data dan Sistem Informasi Pertanian. 2012. Kementrian Pertanian Statistik Konsumsi Pangan Tahun 2012.

- 2015. Statistik Konsumsi Pangan Tahun 2015. Kementrian Pertanian.

- 2018. Kementrian Pertanian Statistik Konsumsi Pangan Tahun 2018.

Ravindran G and Ravindran V. 1988. Changes in the Nutritional composition of cassava (manihot esculenta crantz) leaves during maturity. Food Chemistry 27(4): 299-309.

Ravindran V. 1993. Cassava leaves as animal feed: potential and limitations. Journal of the Science of Food and Agriculture 61(2): 141-50.

Santosa R and Sugeng S. 2004. Effect of Treated Cassava Peel in Diets on Growth Performance of Indonesian Indigenous Sheep. Cuvillier Verlag.

Sivamani S, Chandrasekaran AP, Balajii M, Shanmugaprakash M, Hosseini BA, Baskar R. 2018. Evaluation of the potential of cassavabased residues for biofuels production." Reviews in Environmental Science and Biotechnology. 17(3): 553-70.

Sivamani S and Rajoo B. 2015. Optimization of bioethanol production from cassava peel using statistical experimental design Environmental Progress \& Sustainable Energy 34(2): 567-74.

Sovorawet B and Kongkiattikajorn J. 2012. Bioproduction of ethanol in shf and ssf from cassava stalks. KKU Res Journal. 17(4): 56572. http://resjournal.kku.ac.th.

Suryana, Nurmalina R, Sarianti T, Feryanto. 2012. Kelayakan Industri kecil bioetanol berbahan baku molases di Jawa Tengah. Jurnal Manajemen dan Agribisnis. 9(2): 127-36.

Tanaka K, Koyama M, Pham PT, Rollon AP, Habaki H, Egashira R, Nakasaki K.. 2019. Production of high-concentration bioethanol from cassava stem by repeated hydrolysis and intermittent yeast inoculation. International Biodeterioration and Biodegradation 138 : 17.

Thongkratok R, Khempaka S, and Molee W. 2010. Protein enrichment of cassava pulp using microorganisms fermentation techniques for use as an alternative animal feedstuff. Journal of Animal and Veterinary Advances 9(22): 2859-62.

Ueda S, Zenin CT, Monteiro DA, Park YK. 1981. Production of Ethanol from raw cassava starch by a nonconventional fermentation method. Biotechnology and Bioengineering 23(2): 29199.

Wang D, Bean S, McLaren J, Seib P, Madl,R., Tuinstra M, Shi Y, Lenz M, Wu X. Zhao R. 2008. Grain sorghum is a viable feedstock for ethanol production. Journal of Industrial Microbiology and Biotechnology 35(5): 313-20

Wang W. 2007. Cassava Production for Industrial Utilization in China - Present and Future Perspective. Cassava research and development in Asia (Seventh Region Cassava Workshop, Bangkok, Thailand): 33-38.

Wangpor J, Prayoonyong P, Sakdaronnarong C, Sungpet A, Jonglertjunya W. 2017. Bioethanol production from cassava starch by enzymatic hydrolysis, fermentation and ex-situ nanofiltration. Energy Procedia 138: 883-88. https://doi.org/10.1016/j.egypro.2017.10.116.

Widianingsih R. 2016. Pusat Data dan Sistem Informasi pp. xiv Outlook Komoditas Sub Sektor Tanaman Pangan, Ubi Kayu.

Yang ST, El-Ensashy H, and Thongchul N. 2013. Bioprocessing Technologies in Biorefinery for Sustainable Production of Fuels, Chemicals, and Polymers. John Wiley \& Sons.

Yuwa-Amompitak T. 2010. Ethanol production from cassava starch by selected fungi from tan-koji and saccaromycetes cereviseae. Biotechnology 9(1): 84-88. 